FROM BOW STREET TO BAKER STREET 
Also by Martin A. Kayman

THE MODERNISM OF EZRA POUND

REVOLUTION AND COUNTER-REVOLUTION 


\title{
From Bow Street to Baker Street
}

Mystery, Detection and Narrative

\author{
MARTIN A. KAYMAN \\ Associate Professor and Director of the English \\ Institute, University of Coimbra, Portugal
}

Palgrave Macmillan 
ISBN 978-1-349-21788-5 ISBN 978-1-349-21786-1 (eBook) DOI 10.1007/978-1-349-21786-1

(C) Martin A. Kayman 1992

Softcover reprint of the hardcover 1st edition 1992 978-0-333-46766-4

All rights reserved. For information, write:

Scholarly and Reference Division,

St. Martin's Press, Inc., 175 Fifth Avenue, New York, N.Y. 10010

First published in the United States of America in 1992

ISBN 978-0-312-06798-4

Library of Congress Cataloging-in-Publication Data

Kayman, Martin A., 1953-

From Bow Street to Baker Street : mystery, detection, and narrative / Martin A. Kayman.

p. $\mathrm{cm}$.

Includes bibliographical references and index.

ISBN 978-0-312-06798-4

1. Detective and mystery stories, English-History and criticism.

2. Narration (Rhetoric) I. Title.

PR830.D4K39 1992

823'.087209-dc20

91-22293

CIP 
This book is dedicated to the memory of John Kassman, Dickens scholar, teacher, conversationalist, and friend 


\section{Contents}

Part I Rite and Writing 1

1 Mystery 3

Mystery and Detection 1

Mystery and Narrative $\quad 10$

$\begin{array}{ll}\text { Mystery and Secularization } & 17\end{array}$

Part II Wronging Rights and Righting Wrongs 29

2 Crime 31

The Law 31

The Novel $\quad 43$

Equity $\quad 54$

3 Police 61

Reform 61

The New Mastery of Management $\quad 69$

4 Detectives 81

The Inspector $\quad 81$

The Policeman $\quad 86$

The Detective $\quad 92$

Part III Writing Wrongs and Wrong Writing 99

5 The Romance of the Detective 101

'Detective Literature' 101

Adventures, Memoirs and Recollections $\quad 110$

'A Detective Story' 129

6 Monsters 136

An Idiosyncratic Article $\quad 136$

Creation and Sexuality $\quad 144$

The Confession Revisited 150

The Law of Fiction $\quad 166$

7 Sensation 172

$\begin{array}{ll}\text { The Nervous State } & 172\end{array}$ 
viii

Contents

Cherchez La Femme! 183

Suspicion 192

Part IV Writing Right? 211

8 The Master 213

'An Irrefragable Conclusion' 213

'What Will Be The Next Adventures . . ?' 229

'Who Can Tell?' 234

Notes 241

Index 264 